\title{
CITRA PEREMPUAN DALAM NOVEL GADIS PANTAI KARYA PRAMOEDYA ANANTA TOER (KAJIAN FEMINISME)
}

\author{
Awlia Fajrina Azwar ${ }^{1}$, Dini Andriani², Syahrul Ramadhan ${ }^{3}$ \\ Program Studi Pendidikan Bahasa Indonesia, \\ Fakultas Bahasa dan Seni, Universitas Negeri Padang \\ ${ }^{1}$ Awliafajrina0304@gmail.com, ${ }^{2}$ diniandriani9806@gmail.com
}

\begin{abstract}
Abstrak
Penelitian ini bertujuan untuk mengetahui citra perempuan yang ada di dalam novel Gadis Pantai karya Pramoedya Ananta Toer. Ananta Toer membungkus novel ini sangat berlawanan dengan nilai-nilai feminisme. Penelitian ini menggunakan metode kualitatif yang mana metode yang digunakan dalam melakukan penelitian ini adalah metode deskriptif analitik. Subjek penelitian ini adalah novel Gadis Pantai karya Pramoedya Ananta Toer. Hasil penelitian menunjukkan hasil bahwa novel ini citra perempuan sangat jelas. Pengumpulan data dalam penelitian ini dilakukan menggunakan teknik baca dan catat. Kemudian, analisis data dilakukan dengan teknik deskriptif kualitatif. Ketidakberdayaan seorang Gadis Pantai yang hidup dengan penuh tekanan dari Bendoro. Di sisi lain, Gadis Pantai dianggap terpandang di kampungnya sendiri.
\end{abstract}

Kata Kunci: citra perempuan, novel, gadis Pantai.

\begin{abstract}
This study aims to find out the image of women in Pramoedya Ananta Toer's Beach Girl novel. Ananta Toer framed this novel very contrary to the values of feminism. This study uses a qualitative method in which the method used in conducting this research is descriptive analytical method. The subject of this research is Pramoedya Ananta Toer's Beach Girl novel. The results showed that the novel's image of women was very clear. Data collection in this study was carried out using the technique of reading and recording. Then, data analysis was carried out with qualitative descriptive techniques. The helplessness of a Beach Girl who lives stressfully from Bendoro. On the other hand, Beach Girls are considered respected in their own villages.
\end{abstract}

Keywords: image of women, novels, beach girls.

\section{PENDAHULUAN}

Penggabungan antara hasil imajinasi dan pemikiran pengarangan tentang kehidupan permasalahan sosial yang terdapat di dalam masyarakat dituangkan dalam karya sastra. Karya sastra tidak bersifat terikat, ia bebas menjalar kemana pun. Hal itu merupakan cerminan dari realitas sosial yang sering ditemukan oleh penulis. Apa pun yang ada di pikiran penulis, imajinasi dan hasil pemikiran tersebut yang dihasilkan di karya sastra hanya bersifat fiksi yang berlandaskan realitas sosial.

Masalah-masalah yang terjadi di dalam masyarakat itu diproses oleh pengarang. Ia melahirkan sebuah karya sastra dengan bercermin pada hal-hal yang sudah biasa terjadi. Karya sastra merupakan hasil ciptaan yang pasti diangkat dari realitas sosial. Akan 
tetapi, karya sastra juga dapat dicampur dengan hasil pemikiran si pengarang tersebut. Tidak terlalu kaku dengan realitas sosial yang ada. Karya sastra semakin menarik bagi penikmatnya jika digabungkan hasil pemikiran si penulis sendiri.

Menurut Ratna (dalam Indayani, 2014: 32), pada dasarnya karya sastra memberikan sejumlah informasi sosial, tidak hanya sebatas untuk menopang perkembangan tradisi dan konvensi sastra, tetapi juga berguna untuk meningkatkan kualitas pemahaman pembaca. Selanjutnya, karya sastra dapat memasuki seluruh kehidupan nyata dan memberikan arahan ciri individual pada pola perilaku sosial untuk membentuk keseimbangan secara emosional. Oleh karena itu, selain karya sastra memberikan berbagai informasi, karya sastra juga memberikan arahan kepada individual dalam perilaku sosial.

Di dalam karya sastra ini, pengarang memodifikasi berbagai realitas yang terjadi. Selain itu, pengarang juga membumbui karya sastra dengan pemilihan kata yang indah, ide yang cemerlang, tradisi, sejarah-sejarah, atau pola pikir seseorang atau sekelompok orang. Jadi, meskipun karya sastra berlandaskan realitas, tetapi ia dilengkapi dengan hasil imajinasi pengarang. Begitu juga sebaliknya karya sastra yang bersifat fiksi, selalu mengacu kepada realitas sosial masyarakat.

Novel adalah salah satu bentuk karya sastra yang paling popular di dunia. Bentuk sastra ini paling banyak beredar karena daya komunikasinya yang luas pada masyarakat. Sebagai bahan bacaan, novel dapat dibagi menjadi dua bagian, yaitu karya hiburan dan karya serius (Murpratama, 2012: 5). Salah satu novel karya Pramoedya Ananta Toer yang berjudul Gadis Pantai merupakan salah satu karya sastra yang sangat kental dalam perwujudan kondisi sosial masyarakat. Novel ini berlatarkan di daerah Lasem (Jepara) pada abad ke-19 yang bercerita tentang seorang gadis nelayan berumur 14 tahun yang berasal dari masyarakat pesisir yang dipaksa untuk beradaptasi dengan lingkungan dan gaya hidup keluarga bangsawan. Citra perempuan di dalam novel ini menimbulkan konflik feminisme.

Feminisme digambarkan sebagai konflik yang menuntut kesamaan derajat antara laki-laki dan perempuan. Kesetaraan derajat dan kedudukan ini menimbulkan banyak pengaruh di kehidupan masyarakat. Umumnya masyarakat menganggap perempuan tidak memerlukan pendidikan, tetapi pada zaman sekarang hal itu sangat diperangi oleh kaum perempuan juga. Kartini sebagai pejuang perempuan dalam diskriminasi ini melepaskan belenggu yang memasung perempuan untuk terikat dengan apa yang harus ia lakukan. Keterbatasan ini menjadi salah satu penyebab timbulnya feminisme. Keinginan perempuan yang menjadikan ia setara dengan laki-laki merupakan suatu realitas sosial yang dapat ditemukan di dalam masyarakat.

Feminisme merupakan sebuah gerakan yang menuntut kesamaan dan keadilan hak baik dalam hal politik, sosial, dan ekonomi antara kaum perempuan dan pria tanpa adanya diskriminasi. Selain itu, feminisme ini juga merupakan suatu gerakan emansipasi wanita, gerakan ini dengan lantang menyuarakan tentang perbaikan kedudukan wanita dan menolak perbedaan derajat antara pria dan perempuan. Oleh karena itu, feminisme bertujuan untuk meningkatkan kedudukan dan derajat perempuan agar sejajar dengan kedudukan dan derajat laki-laki. Perjuangan feminisme untuk mencapai tujuan ini mencangkup banyak cara. Salah satu caranya adalah mendapatkan hak dan peluang yang sama dengan yang dimiliki laki-laki. Di dalam kajian feminisme sastra haruslah terdapat sebuah pertentangan atau perlawanan yang dilakukan seorang perempuan tersebut sebagai bentuk protes atau usaha menolak adanya ketidakadilan terhadap kaum 
perempuan. Jika tidak ada penentangan atau perlawanan pihak perempuan maka itu tidak dapat disebut dengan feminisme.

Menurut Tasharofi (2014), kritik feminis menyarankan hak yang sama untuk semua wanita di semua bidang kehidupan: sosial, politik, profesional, secara pribadi, ekonomi, estetis, dan psikologis. Mustafa (2018) menjelaskan bahwa feminisme pada umunya fokus pada wanita, hak, dan membela hak-hak wanita yang menjadi tren setelah abad ke-20. Selain itu, feminisme juga memengaruhi dunia sastra, termasuk dalam karya seni oleh beberapa novelis. Menurut Yazbahar (2011), banyak topik yang menarik untuk dibahas mengenai kaum perempuan, seperti kesetaraan yang dibahas dalam novel. Di arah ini perjuangan perempuan adalah perjuangan individu yang dianggap sebagai permasalahan sosial. Selain itu, gerakan perempuan feminis, dimulai di Barat pada 1980an dan mulai menyebar di negara kita secara alami dalam mengangkat kedudukan perempuan dan masalah-masalahnya di masyarakat.

Menurut Lótter (2000: 507), feminisme secara mantap menjadi filosofi pembebasan dengan dampak kuat pada politik melalui gerakan perempuan. Pada saat ini, feminisme masih menuntut perhatian serius karena keragaman sosialnya dan evaluasi normatif institusi, praktik, konvensi, dan kebiasaan. Menurut Ryan (2010), feminisme mendorong perempuan untuk merebut apapun kesempatan untuk menolak diam yang diberlakukan pada mereka dan berani menyuarakan keinginan mereka.

Feminisme adalah ideologi yang membahas mengenai persamaan hak pria dengan perempuan. Kata feminisme berasal dari bahasa Latin, yaitu "femina" berarti memiliki karakter keperempuanan. Rose (dalam Juanda dan Aziz, 2018) menjelaskan bahwa gerakan feminis dapat menjadi salah satu usaha untuk meningkatkan kedudukan serta derajat kaum perempuan agar sejajar atau sama dengan laki-laki. Menurut Gamble (dalam Manurung, 2013), feminisme merupakan paham kontiniu yang menuntut persamaan antara hak wanita dan laki-laki. Dalam hal ini wanita tidak lagi merasa tertindas oleh kaum laki-laki. Feminisme atau sering disebut kritik sastra feminis merupakan pendekatan yang menitikberatkan pada permasalahan wanita, yaitu melihat sesuatu dari sudut pandang wanita. Sebab, apa pun yang ada dalam kenyataan maupun dalam karya sastra selalu dilihat dari sudut laki-laki, sedangkan posisi perempuan hanya akan muncul jika kaum laki-laki itu berinteraksi dengan kaum wanita (Andri, 2015).

Menurut Setiyono (2015), gerakan feminisme dapat melahirkan konsep dan teoriteori yang secara khusus berhubungan dengan analisis kaum perempuan. Feminisme selalu dikaitkan dengan jenis kelamin (gender). Baik feminisme maupun gender memiliki muara persoalan yang sama, yaitu menuntut persamaan hak yang sama dengan laki-laki. Gerakan feminisme dan gender terjadi karena kondisi perempuan yang tersubordinasi oleh kebudayaan. Menurut Musrifa (2018), fenomena yang terdapat di masyarakat dan beberapa karya sastra melahirkan gagasan feminisme yang menuntut adanya kesetaraan perempuan dengan kaum laki-laki. Perjuangan feminisme menuntut kesetaraan hak-hak demokrasi serta ketidakadilan terhadap hak-hak dasar kehidupan kaum perempuan. Tujuan feminisme adalah meningkatkan kedudukan dan derajat perempuan agar sama atau sejajar dengan kedudukan serta derajat pria. Kedudukan perempuan merupakan kesadaran terhadap nasib, cita-cita, dan hak yang membuat perempuan bangkit untuk memperjuangkan kesetaraan dan menjadikannya sebagai perempuan kuasa.

\section{METODE PENELITIAN}

Panelitian ini merupakan penelitian kualitatif. Menurut Sugiyono (2010:8), instrumen penelitian kualitatif adalah orang atau human instrumen, yaitu peneliti sendiri. Subjek 
penelitian ini adalah novel Gadis Pantai karya Pramoedya Ananta Toer. Metode yang digunakan dalam melakukan penelitian ini adalah metode deskriptif analitik. Penelitian deskriptif merupakan penelitian yang bertujuan untuk menyelidiki keadaan, kondisi, atau hal lain-lain yang hasilnya dijelaskan dalam bentuk penelitian. Metode deskriptif analitik bertujuan untuk mendeskripsikan, menggambarkan, atau menguraikan secara sistematis faktual dan aktual tentang fakta-fakta, sifat-sifat serta hubungan antarfenomena yang diteliti. Data yang diambil adalah data yang berkaitan dengan citra perempuan dalam novel Gadis Pantai dalam kajian sastra feminisme. Pengumpulan data dalam penelitian ini dilakukan menggunakan teknik baca dan catat. Kemudian, analisis data dilakukan dengan teknik deskriptif kualitatif.

\section{HASIL DAN PEMBAHASAN}

Novel Gadis Pantai karya Pramoedya Ananta Toer menceritakan tentang kehidupan seorang gadis pantai dinikahkan oleh orang tuanya dengan seorang Bendoro, bangsawan Jawa di masa pemerintahan kolonial. Namun, baik orang tua atau tetua desa yang mendampinginya tidak tahu bahwa gadis yang mereka anggap beruntung itu hanya akan menjadi istri percobaan saja. Dalam kalangan bangsawan, istri yang dianggap sah bagi seorang bangsawan adalah seorang perempuan yang juga berasal dari kalangan bangsawan saja.

Semenjak saat itu Gadis Pantai menjalani hari-harinya di istana milik sang Bendoro. Di sana ia dipanggil dengan sebutan, "Mas Nganten". Selama hidup di istana Gadis Pantai mempunyai sosok ibu pengganti. Ia adalah pelayan pribadi Gadis Pantai. Selama hidup di istana, ia merasa tidak lagi memiliki kebebasan. Meskipun di istana ia bisa memerintah banyak pelayan, tapi ia tetap merasa sendiri dan kesepian karena dirinya tak diperbolehkan untuk bergaul dengan masyarakat sekitar, bahkan sekedar tertawa pun juga tidak diizinkan bagi istri bendoro.

Saat usia Gadis Pantai masih sangat remaja, ia harus kehilangan keperawanannya, ia mengalami syok sesaat. Semenjak saat itu, ia selalu dihantui rasa takut ditinggalkan Bendoro jika ia dianggap tak lagi berbakti. Keperawanannya sudah diambil dan ia merasa hidupnya hanya bergantung pada belas kasih bendoronya. Oleh karena itu, ia pun memutuskan untuk mulai belajar menjadi istri bangsawan sepantasnya dari pelayannya. Namun, sayangnya sang pelayan yang telah dianggap ibu oleh Gadis Pantai dipecat Bendoro karena sang pelayan membela Gadis Pantai yang difitnah oleh saudara Bendoro. Gadis Pantai hanya bisa menangis. Tak begitu lama setelah si pelayan pergi, ia mendapat pelayan pribadi baru yang sangat muda, namun pandangannya selalu sinis melihat Gadis Pantai.

Gadis Pantai sangat merindukan kampung halamannya dan ia pun memutuskan untuk meminta izin kepada Bendoro. Bendoro mengizinkan ia pulang kampung jika ditemani Mardinah, pelayan barunya. Di kampungnya, ia disambut dengan sangat baik karena masyarakat kampung menganggap Gadis Pantai sebagai seorang bangsawan. Bahkan, mereka pun berusaha menjaga jarak dan tak berani menyinggungnya sama sekali. Tidak hanya masyarakat kampung saja, bahkan ibunya sendiri juga menjaga jarak dan memperlakukannya bak ratu. Bukannya bahagia, Gadis Pantai merasa sangat sedih melihat hal ini. Ia ingin dicintai dan dikasihi ibunya, bukan disembah dan ditakuti bak ratu. Ia merasa kehilangan semua orang karena status bangsawan yang melekat pada dirinya.

Saat masih tinggal di kampungnya, sebuah kejadian aneh terjadi. Seorang penyusup ditangkap dan ternyatanya penyusup itu adalah suruhan Mardinah. Mardinah 
datang kembali ke kampung Gadis Pantai dan mengatakan ia diutus Bendoro untuk menjemput Gadis Pantai. Namun, warga kampung tidak mengizinknnya karena menganggap hal itu sangat mencurigakan. Setelah dipaksa untuk mengaku dan berbicara jujur, akhirnya Mardinah mengaku bahwa ia tidak disuruh oleh Bendoro melainkan seorang bangsawan Demak. Ia diminta membunuh Gadis Pantai supaya Bendoro mau segera menikah dengan perempuan yang berasal dari keluarga bangsawan. Sebagai hukumannya, Mardinah dipaksa menikah dengan seorang bujang di kampung itu yang tak laku-laku. Sementara itu, akhirnya Gadis Pantai kembali ke rumah Bendoro.

Di istana Bendoro, ia kembali merasa kekangan. Namun, kandungan dalam perutnya saat ini, cukup bisa menghiburnya di kala ia merasakan kesepian. Waktu terus berjalan, sampai akhirnya Gadis Pantai melahirkan seorang putri. Ia mempersembahkan putrinya itu pada Bendoro, tetapi tak digubris. Bendoro justru meminta ayah Gadis Pantai untuk datang ke istana. Setelah menghadap Bendoro, barulah ayah Gadis Pantai sadar bahwa putrinya akan dicerai. Bukan hanya itu, ia juga diminta untuk meninggalkan cucunya di istana. Gadis Pantai yang mendengar kabar ini sangat sedih. Namun, ia juga tak bisa berbuat apa-apa. Saat berusaha melawan, ia dibentak dan diusir dengan kasar oleh para pengawal Bendoro.

Selama perjalanan menuju kampungnya, Gadis Pantai hanya bisa memikirkan bagaimana ia mengahadapi ibu dan masyarakat kampungnya nanti. Apa yang bisa ia jelaskan kepada mereka? Bagaimana pandangan mereka setelah mendengarkan kejadian ini? Setelah merenungkan semua itu, Gadis Pantai akhirnya memutuskan pamit pada ayahnya untuk pergi dan hidup bersama pelayan pribadinya yang ia tahu hidup di suatu daerah.

\section{Posisi Gadis Pantai sebagai Perempuan Jawa}

Dalam masyarakat Jawa, posisi perempuan dikelompokkan menjadi dua kelompok. Pertama, perempuan Jawa berada pada posisi yang tinggi. Hal ini dapat dilihat dari peran perempuan dalam kehidupan, baik itu kehidupan di keluarga maupun masyarakat terutama dalam bidang ekonomi. Kedua, peran penting perempuan dalam sektor ekonomi belum tentu menunjukkan tingginya status dan kedudukan perempuan Jawa. Dalam novel Gadis Pantai karya Pramoedya Ananta Toer, Gadis Pantai berusaha untuk mensejajarkan posisinya sama dengan manusia lain. Dalam novel ini, Gadis Pantai diceritakan sebagai gadis yang cantik dan muda, ia berasal dari kampung nelayan, dan diperistri oleh seorang priyayi Bendoro dalam usia belia, yaitu 14 tahun. Perbedaan status sosial membuat Gadis Pantai tak bisa menduduki status menjadi istri sesungguhnya dari Bendoro. Gadis Pantai hanya dianggap sebagai isteri percobaan selama Bendoro belum menemukan seorang perempuan dari keturunan Bangsawan untuk dijadikan isteri.

Dalam novel ini, posisi Gadis Pantai dianggap sangat rendah, ia dinikahi secara paksa untuk memenuhi kebutuhan biologis Bendoro. Kemudian, dia diasingkan, dan hakhak untuk bebas pun tak bisa lagi ia rasakan. Bahkan, setelah ia melahirkan seorang putri, ia langsung diceraikan, dipisahkan dari anaknya, dan diusir dari rumah Bendoro. Oleh karena itu, dapat disimpulkan bahwa perempuan dalam Gadis Pantai masih menempati posisi yang terabaikan karena status sosialnya yang dianggap rendah. Hal yang paling menyedihkan adalah suami dan keluarganya sendirilah yang mengantarkannya pada posisi terendah dan kesengsaraan. 


\section{Citra Perempuan dari Aspek Fisik dalam Gadis Pantai}

Citra fisik tokoh utama dalam novel Gadis Pantai digambarkan dengan bentuk anggota tubuh tokoh yang digambarkan penulis. Gadis Pantai memiliki kulit kuning langsat yang berarti bersih dan tidak hitam, tubuh yang kecil, mata agak sipit, hidung alakadarnya. Hal ini membuktikan bahwa Gadis Pantai adalah gadis tercantik di kampungnya. Tangan Gadis Pantai yang kasar menunjukkan bahwa dari kecil ia sudah bekerja keras untuk membantu orang tuanya.

"Bagi wanita yang masih muda, Mas Nganten, sebenarnya tak ada kesulitan hidup di dunia, apalagi kalau ia cantik, dan rodi sudah tidak ada lagi." (Gadis Pantai, hlm.88).

Selain bentuk tubuhnya, penulis juga menjelaskan bahwa Gadis Pantai memiliki sifat yang kekanak-kanakan. Hal ini dapat dilihat dari tingkah laku Gadis Pantai saat berinteraksi dengan emak dan bapaknya. Ia masih menunjukkan sikap manja dan kekanak-kanakannya.

"Bawa aku pada emak, aku mau pulang, pulang ke kampung." (Gadis Pantai, hlm. 38)

"Gadis Pantai melompat, waktu dilihatnya emak memasuki pintu, ia lari menubruk wanita tua itu dan merangkulnya. Mah, emak mari pulang." (Gadis Pantai, hlm. 44)

\section{Citra Perempuan dari Segi Aspek Psikis dalam Gadis Pantai}

Citra perempuan dari segi aspek psikis ditunjukkan melalui perasaan dan pikiran yang dialami oleh Gadis Pantai. Pertama, perasaan sedih. Sedih adalah kesakitan psikologi yang berkaitan dengan perasaan kekurangan, kehilangan, putus asa, dan tidak dapat melakukan apa-apa. Misalnya, Gadis Pantai sangat sedih atas kepergian pembantu setianya, ia merasa orang sebaik itu harus menanggung nasib seberat ini. Kedua, perasaan rindu. Perasaan rindu adalah perasaan yang dimiliki setiap orang yamg ditujukan kepada siapa saja terutama untuk orang yang disayangnya. Perasaan rindu ini dirasakan Gadis Pantai terhadap suaminya, Bendoro. Ketiga, ketakutan. Ketakutan adalah perasaan tidak menyenangkan yang disebabkan karena adanya persepsi bahaya yang nyata, atau dibayangkan. Hal ini dapat digambarkan dari Gadis Pantai yang tak dapat menahan hatinya yang selama ini diaduk ketakutan dan kekhawatiran. Keempat, cemburu. Cemburu adalah perasaan negative, seperti takut kehilangan, cemas, dan khawatir melihat seseorang yang disayangi dekat dengan orang lain. Perasaan inilah yang dirasakan Gadis Pantai saat melihat dan mendengar bahwa Bendoro sedang bersama perempuan lain. Hal ini dapat digambarkan dari hati Gadis Pantai yang berseri riang dan sekejap ia melupakan rasa cemburunya. Naluri keibuannya mulai bekerja dan lebih keras lagi naluri ini menjejaki darah hidup suaminya.

\section{Kekerasan terhadap Perempuan}

Fakih (dalam Hayati, 2012: 166) menjelaskan ada delapan bentuk kekerasan yang disebabkan oleh pandangan bias gender. Kedelapan kekerasan itu meliputi, pemerkosaan, pemukulan dan serangan fisik, penyiksaan yang mengarah kepada organ alat kelamin, kekerasan dalam bentuk pelacuran (ekonomi), kekerasan dalam bentuk pornografi, kekerasan dalam bentuk pemaksaan sterilisasi dalam Keluarga Berencana, kekerasan terselubung serta pelecehan seksual. Menurut Hayati (2012: 166), kekerasan merupakan suatu serangan terhadap fisik maupun psikologi sesorang. Salah satu sumber 
kekerasan yang terjadi disebabkan oleh pandangan yang bias gender. Kekerasan yang terjadi tidak hanya kekerasan fisik, tetapi juga psikologis.

Menurut Werdiningsih (2016: 107), kekerasan terhadap perempuan yang dilakukan oleh laki-laki maupun perempuan merupakan bagian dari kehidupan sosial masyarakat. Kehidupan masyarakat tidak hanya dapat dilihat secara langsung, tetapi juga tecermin dalam karya sastra. Menurut Muhajarah (2016: 130), bentuk kekerasan terhadap perempuan itu beragam. Mulai dari kekerasan fisik, psikologis, ekonomi, sampai kekerasan seksual. Jelasnya kekerasan terhadap perempuan (isteri) sebagaimana yang tertuang dalam rumusan Deklarasi PBB, yaitu tentang Deklarasi Penghapusan Tindak Kekerasan terhadap Perempuan adalah segala tindakan berdasarkan perbedaan jenis kelamin yang berakibat atau mungkin kesengsaraan atau penderitaan perempuan secara fisik, seksual atau psikologis termasuk ancaman tindakan, pemaksaan atau perampasan kemerdekaan secara sewenang-wenang baik yang terjadi di depan umum atau dalam kehidupan pribadi/keluarga.

Kekerasan terhadap perempuan merupakan segala macam tindakan yang dapat mengakibatkan penderitaan fisik, psikologis, seksual terhadap perempuan. Tindakan yang dapat dikategorikan dalam bentuk kekerasan, antara lain ancaman, pemaksaan atau pembatasan kebebasan, dan membatasi hak-hak sebagai perempuan. Kekerasan terhadap perempuan disebabkan karena adanya diskriminasi gender, yaitu adanya perlakuan yang berbeda terhadap individu yang didasarkan pada gender. Masyarakat menganggap status sosial laki-laki lebih tinggi dibandingkan perempuan.

\section{Kekerasan fisik}

Menurut Poerwandari (dalam Werdiningsih, 2016: 107), dimensi kekerasan fisik mencakup memukul, menampar, mencekik, menendang, melempar barang ke tubuh korban, menginjak, melukai dengan tangan kosong atau alat/senjata, dan membunuh. Bentuk kekerasan fisik yang diterima korban dapat dilihat secara langsung pada fisik korban tersebut seperti berdarah, patah tulang, memar, pingsan dan bentuk lainnya yang lebih berat. Pada novel Gadis Pantai ini, penulis memberikan fokus kekerasan tersebut terhadap perempuan yang menjadi tokoh utama dalam novel ini. Novel ini mengangkat tentang kajian feminisme.

Berdasarkan dari segi ceritanya, novel ini menggambarkan sosok perempuan yang lemah, tak berdaya, dan dipandang rendah. Perempuan dianggap sebagai makhluk yang tidak akan berani menentang dan memberontak. Sebagai gambaran sifat perempuan yang tidak berdaya, lemah lembut, penurut, pasrah, tokoh utama dalam novel ini mengalami penindasan. Baik dari segi pendidikan, norma-norma, dan hak untuk menentukan pendamping hidup. Kekerasan yang dialami perempuan dalam niovel ini disebabkan karena adanya deskriminasi gender ketika posisi laki-laki dianggap lebih tinggi dibandingkan posisi perempuan.

Dalam novel Gadis Pantai ini tidak diperlihatkan begitu jelas kekerasan fisik yang dilakukan terhadap perempuan, namun kekerasan yang dialami Gadis Pantai disebabkan karena adanya budaya patriarki.

"Apa salahku?"

"Salah Mas Nganten seperti sahaya, salah kita, berasal dari orang kebanyakan.”

"Lantas Mbok, lantas?

"Kita sudah ditakdirkan oleh orang yang kita puji dan kita sembah buat jadi pasangan orang rendahan. Kalau tidak ada orang-orang rendahan, tentu tidak ada orang atasan." 
"Aku ini, Mbok aku ini orang apa? Rendahan? Atasan?"

"Rendahan Mas Nganten, maafkan sahayaa, tapi menumpang di tempat atasan."

"Jadi apa yang mesti kuperbuat?"

"Ah, beberapa kali sudah sahaya katakan. Mengabdi Mas Nganten. Sujud, takluk sampai tanah pada Bendoro." (Gadis Pantai, hlm. 99)

Dalam novel Gadis Pantai, tokoh utama hanya bisa pasrah dengan perlakuan suaminya, ia tidak berani membentak permintaan suaminya, bahkan dia rela memenuhi semua keinginan suaminya, seperi seorang istri yang dituntut melayani suaminya dengan maksimal. Semua perlakuan kasar dari suaminya diterimanya saja tanpa melakukan perlawanan sedikit pun.

\section{Kekerasan psikologis}

Menurut Muhajarah (2016: 131), kekerasan psikis/emosional (emotional abuse) seperti rasa cemburu atau rasa memiliki yang berlebihan, merusak barang-barang milik pribadi mengancam untuk bunuh diri, melakukan pengawasan dan manipulasi, mengisolasi dari kawan-kawan dan keluarganya, dicaci maki, mengancam kehidupan pasangannya atau melukai orang yang dianggap dekat atau menganiaya binatang peliharaannya, menanamkan perasan takut melalui intimidasi, ingkar janji, merusak hubungan orang tua anak atau saudara dan sebagainya.

Menurut Poerwandari (dalam Werdiningsih, 2016: 106), kekerasan psikologis mencakup berteriak-teriak, menyumpahi, mengancam, merendahkan, mengatur, melecehkan, menguntit, dan memata-matai, dan tindakan-tindakan lain yang menimbulkan rasa takut, termasuk yang diarahkan kepada orang-orang dekat korban, misalnya suami, anak, keluarga, dan teman dekat.

Kekerasan psikologis yang dialami tokoh Gadis Pantai dalam novel Gadis Pantai adalah mengenai kawin paksa. Dalam cerita Gadis Pantai, tokoh Gadis Pantai dikawinkan secara paksa oleh keluarganya dengan seorang laki-laki yang berasal dari golongan bangsawan. Gadis pantai dipaksa menikah oleh keluarganya dengan tujuan untuk meningkatkan derajat keluarga di mata masyarakat, sehingga keluarga Gadis Pantai disegani oleh tetangganya. Gadis Pantai tidak pernah mengharapkan menikah dengan orang kaya. Sebenarnya, Gadis Pantai lebih memilih menjadi anak nelayan daripada menjadi istri ningrat.

Selama pernikahannya dengan Bendoro, Gadis Pantai merasa tertekan. Ia tidak bisa lagi bermain dengan bebas, merasakan masa-masa remajanya. Hidupnya penuh dengan aturan, semua perintah dari Bendoro harus dilaksanakannya. Bahkan, perasaan cemburu, terluka, dan sedih seringkali dirasakannya. Seperti saat melihat Bendoro bersama dengan perempuan lain. Begitu juga, saat mengetahui bahwa ia diceraikan Bendoro dan anak yang baru ia lahirkan diambil paksa oleh Bendoro, di saat itulah hatinya sangat sedih dan terluka.

"Kemarin malam ia telah dinikahkan. Dinikahkan dengan sebilah keris. Detik itu ia tahu: kini ia bukan anak bapaknya lagi. Ia bukan anak emaknya lagi. Kini ia istri sebilah keris, wakil seseorang yang tak pernah dilihatnya seumur hidup [...] Ah, hanya orang kebanyakan dikawini dengan keris."(Gadis Pantai, hlm 21)

\section{Kekerasan seksual}

Poerwandari (dalam Werdiningsih, 2016: 109), kekerasan seksual meliputi tindakan yang mengarah pada ajakan/desakan seksual seperti menyentuh, meraba, atau mencium. Selain 
itu, yang termasuk dalam kekerasan seksual adalah melakukan tindakan-tindakan yang tidak dikehendaki korban, seperti memaksa korban untuk menonton produk pornografi, gurauan-gurauan seksual yang tidak dikehendaki korban, ucapan-ucapan yang merendahkan dan melecehkan dengan mengarah pada aspek jenis kelamin atau seks korban, memaksa berhubungan seks dengan kekerasan fisik maupun tidak, memaksa korban melakukan aktivitas-aktivitas seksual yang tidak disukai, merendahkan, dan pornografi dengan dampak yang sangat luas bagi perempuan.

Dalam novel Gadis Pantai ini, diceritakan Bendoro melakukan hubungan intim dengan Gadis Pantai saat Gadis Pantai masih berumur 14 tahun. Bahkan, pada saat Bendoro melakukan hubungan intim dengan Gadis Pantai. Gadis Pantai tak mengerti sama sekali, apa yang terjadi.

"Karena dia menikah dengan diperintah dan keharusan, maka ketika menjalani hubungan suami-istri dia tidak mengetahui secara pasti. Hubungan mereka terjadi tanpa kesepakatan satu sama lain. Pada saat pertama kali berhubungan sebagai suami istri, dia tidak mengetahui terjadinya. Dia hanya merasakan sakit ketika bangun tidur...."

"Aku sakit, Mbok. Bawa aku ke kamar mandi," diulurkannya kedua tangannya minta dibangunkan. Wanita itu meraihkan lengannya, di bawah tengkuk Gadis Pantai, mendudukannya, merapikan rambutnya yang kacau balau, membenahi baju dan kainnya yang lepas porak poranda, menarik-narik seprai yang berkerut di sana-sini.

"Ooh! Mas Nganten tidak sakit," kiranya bujang sekali lagi, dan menurunkannya dari ranjang.

"Mbok," sepantun panggilan dengan suara lembut.

"Tidak apa-apa Mas Nganten. Yang sudah terjadi ini takkan terulang lagi.", "Apa yang sudah terjadi, mBok?"

Dan setelah Gadis Pantai terpapah berdiri, bujang menunjuk pada sprai yang dihiasi beberapa titik merah kecoklatan, berkata, "Sedikit kesakitan Mas Nganten dan beberapa titik darah setelah setengah tahun ini tidaklah apa-apa."

\section{Ketidakberdayaan Perempuan Kelas Bawah dalam Sebuah Pernikahan dengan Seorang Bangsawan}

Ketidakberdayaan perempuan dalam novel Gadis Pantai ini tergambar pada sosok tokoh utama dalam cerita ini, yaitu Gadis Pantai. Gadis Pantai adalah seorang gadis belia yang dipaksa menikah oleh keluarganya dengan seorang bangsawan. Gadis Pantai tidak dapat memilih dan menentukan sendiri pasangan hidupnya. Ia tak bisa menolak atau melakukan perlawanan. Ia hanya bisa menerimanya dan mengikuti kemauan dari keluarganya.

Semenjak menikah, Gadis Pantai selalu dikekang dan tidak boleh bergaul dengan masyarakat sekitar. Ia hanya dijadikan isteri percobaan selama Bendoro belum menemukan perempuan dengan status sosial yang sama dengannya untuk dijadikan isteri. Ia juga diperlakukan semena-mena oleh Bendoro. Namun, sayangnya Gadis Pantai hanya bisa pasrah dan tak dapat melakukan pembelaan sama sekali. Bahkan, saat ananknya diambil oleh Bendoro, Gadis Pantai juga tidak bisa berbuat apa-apa. Ia hanya bisa pasrah menerima keadaanya.

\section{SIMPULAN}

Berdasarkan pembahasan mengenai citra perempuan dalam novel Gadis Pantai dapat disimpulkan bahwa feminisme adalah suatu konflik yang menuntut kesetaraan derajat 
antara kaum laki-laki dan kaum perempuan. Hal ini menjadi dasar dalam pembahasan dalam citra perempuan dalam novel Gadis Pantai. Kajian feminisme dalam novel Gadis Pantai ada beberapa hal yang perlu di telaah. Pertama, posisi Gadis Pantai sebagai perempuan Jawa. Posisi perempuan dikelompokan menjadi dua kelompok. Pertama, perempuan Jawa berada pada posisi yang tinggi. Hal ini dapat dilihat dari peran perempuan dalam kehidupan, baik itu kehidupan di keluarga maupun masyarakat terutama dalam bidang ekonomi. Kedua, peran penting perempuan dalam sektor ekonomi belum tentu menunjukkan tingginya status dan kedudukan perempuan Jawa. Kedua, citra perempuan dari aspek fisik. Ketiga, citra perempuan dari aspek psikis. Keempat, kekerasan perempuan, yang terbagi atas kekerasan fisik, psikologis, dan seksual. Novel Gadis Pantai dibingkis sedemikian rupa untuk mencanangkan kepada pembaca bagaimana feminisme yang ada pada gadis pantai.

\section{DAFTAR PUSTAKA}

Andri, L. (2015). Feminisme dalam prosa lama 'Tjerita Nji Paina' Karangan H. Koomer. Jurnal Humanika, 22 (2), https://ejournal.undip.ac.id/index.php/humanika/article /view/11735/8978, diunduh 15 Maret 2019.

Hayati, Y. (2012). Representasi ketidakadilan gender dalam cerita dari Blora Karya Pramudya Ananta Toer: Kajian feminism. Atavisme, 15 (2), http://atavisme.web.id/index.php/atavisme/article/view/57/51, diunduh 3 Mei 2019.

Indayani. (2014). Feminisme dalam novel Bibir Merah Karya Achmad Munif. Jurnal Buana Basastra, 1, jurnal.unipasby.ac.id/index.php/bastra/article/download/175/ 76/, diunduh 22 April 2019.

Juanda, \& Azis. (2018). Penyingkapan citra perempuan cerpen media indonesia: Kajian feminisme. Jurnal Lingua, 15 (2), http://lingua.pusatbahasa.or.id/index.php /lingua/article/view/478/412, diunduh 15 Maret 2019.

Lótter, H.P.P. (2000). The South African constitution requires men to be feminist. Koers Journal, 65 (4), http://www.koersjournal.org.za/index.php/koers/article/ view/488/613, diunduh 16 Maret 2019.

Manurung, D. (2013). Analisis unsur feminisme dalam kumpulan cerpen Perempuan Berlipstik Kapur karya Esti Nuryanti Kasam. Artikel E-Journal, http://jurnal.umrah.ac.id/wp-content/uploads/2013/08/Dorti-Manurung090388201072.pdf, diunduh 15 Maret 2019.

Muhajarah, K. (2016). Kekerasan terhadap perempuan dalam rumah tangga: Perspektif sosio-budaya, hukum, dan agama. SAWWA, journal.walisongo.ac.id/index.php /sawwa/article/download/1452/1076, diunduh 3 Mei 2019.

Murpratama, D. A. (2012). Aspek sosial dalam novel Pusaran Arus Waktu karya Gola Gong: Tinjauan sosiologi sastra dan implementasinya dalam pembelajaran sastra di SMA. Skripsi, Http://Eprints.Ums.Ac.Id/21035/20/ Jurnal_Penelitian.Pdf, diunduh 22 April 2019 
Musrifah. (2018). Feminisme liberal dalam novel Sepenggal Bulan Untukmu karya Zhaenal Fanani. Jurnal Lingua, 2 (1), http://journal.um-surabaya.ac.id/index. php/lingua/article/view/1438/1244, diunduh 15 Maret 2019.

Mustafa. (2018). Feminist discourses in the novel of a Marriage Under a Comet. Idil Sanat ve Dil Dergisi Journal, 7 (43), http://www.idildergisi.com/makale /pdf/1520866006.pdf, diunduh 16 Maret 2019.

Ryan, M. (2010). A Feminism of their own?: Irish women's history and contemporary irish women's writing. Estudios Irlandeses Journal, 5, http://www.estudiosirlandeses.org/wpcontent/uploads/2013/05/Mary_Ryan.pdf, diunduh 16 Maret 2019.

Setiyono, J. (2015). Kajian feminisme dalam cerpen Lelaki ke-1000 di Ranjangku karya Emha Ainun Najib. Jurnal Edutama, 2 (1). http://ejurnal.ikippgribojonegoro.ac.id /index.php/JPE/article/view/14/13, diunduh 15 Maret 2019.

Sugiyono. (2010). Metode Penelitian Kuantitatif dan Kualitatif dan R\&D. Bandung: Alfabeta.

Tasharofi, P. (2014). Domestic violence in Zora Neale Hurston's their eyes were watching God: A Feminist reading. International Journal of Applied Linguistics \& English Literature, 3 (4), http://www.journals.aiac.org.au/index.php/IJALEL/article/view /1146/1160, diunduh 16 Maret 2019.

Werdiningsih, Y. K. (2016). Kekerasan terhadap tokoh utama perempuan dalam novel Kinanti karya Margareth Widhy Pratiwi. Jurnal Atavisme, 19 (1). http://atavisme.web.id/index.php/atavisme/article/view/41/178, diunduh 3 Mei 2019.

Yazbahar, Z. (2011). Afet (Muhteremoğlu) Ilgaz'in Romanlarinda Kadin Sorunsali. Turkish Studies - International Periodical For The Languages, Literature and History of Turkish or Turkic journal, 6 (2), http://turkishstudies.net/ Makaleler/898322316_60Yazbahar\%20Zehra.pdf, diunduh 16 Maret 2019. 